\title{
The Effect of Employee Engagement and Organizational Citizenship Behavior on the Performance of Employees of the Research \& Development and Education \& Training Agency of the Ministry of Religion of the Republic of Indonesia
}

\author{
Dian Hafit Syaifullah ${ }^{a}$, Sunarta ${ }^{b}$, Bambang Dwi Hartono ${ }^{c}$ \\ ${ }^{\text {a}}$ Research and Development and Training Agency of the Ministry of Religion of the Republic of Indonesia \\ ${ }^{\mathrm{b}, \mathrm{c}}$ Lecturer of Postgraduate of Muhammadiyah Prof. Dr. Hamka University, Jakarta, Indonesia.
}

Article History: Received: 11 January 2021; Accepted: 27 February 2021; Published online: 5 April 2021

\begin{abstract}
The management of human resources at the Secretariat of the Research and Development and Training Agency (a public organization that is identical to religious values) experiences problems because the importance of employee performance, employee engagement, and organizational behaviour are still below 75 . This study aims to determine whether employee engagement and organizational citizenship behaviour positively and significantly impact employee performance. This research finds that employee engagement has a positive and significant impact on employee performance, while organizational citizenship behaviour has a negative and insignificant impact on employee performance. This research supports previous research, which states that employee engagement positively and significantly impacts employee performance. However, this research refutes previous research applied to private organizations, which states that organizational citizenship behaviour has a significant positive impact on employee performance.
\end{abstract}

Keywords: Employee Engagement, Organizational Citizenship Behaviour, Performance.

\section{Introduction}

Employee performance is of public concern because employees are one of the government's pillars in realizing a world-class government. The target of world-class government or world-class government in 2024 can only be realized with two main things: high-performance ASN with 4.0 technology. Characteristics of ASN performance that support the world-class government are 1) integrity, 2) nationalism, 3) professionalism, 4) global perspective, mastering IT and foreign languages, hospitality, networking, and entrepreneurship. Worldclass employee performance will support the goal of bureaucratic reform 4.0, namely in the form of government performance, which has indicators: 1) acceleration of service, 2) service efficiency, 3) accuracy of service, 4) work flexibility, and 5) social impact.

Among the factors that affect employee performance is employee engagement. Employee engagement, which is translated into a language as employee engagement, is one factor in realizing the success of organizational goals. Perrin's Global Workforce Study in Alexandri et al. (2018) states that employee engagement is the willingness and ability of individual employees to realize organizational success in achieving goals by contributing to sustainable thinking and efforts. This employee engagement is exciting to study because conditions in the Secretariat of the Research and Development and Training Agency have problems in the relationship between employees, which is one of the indicators of employee engagement.

Based on preliminary research, the Secretariat of the Research and Development and Training Agency's employee engagement shows an average score of 73 is still below the target of 75 . With the lowest score of 70 on the absorption dimension. Even in the dimensions of vigor and dedication, some employees feel that they have never been passionate and dedicated at work. From a phenomenological point of view, the Secretariat of the Research and Development and Training Agency's personnel guidance officer revealed this (Fachrudin, 2019). Currently, there is a condition of vertical employee separation. In fact, vertical relations have experienced the phenomenon of the emergence of brave subordinates' attitudes to show reluctance and even rejection of certain assignments from their superiors. Even though those tasks are still within the scope of their job duties on the grounds, they are already burdened with many jobs so that they do not or do not want to add other jobs. What is worrying is that the refusal was carried out with an expression that was not polite in the relationship between superiors and subordinates. Ideally, a harmonious vertical relationship will be the basis for mutually supportive networking within the organization, within the same subdivision, and between divisions and among echelons above it to improve organizational performance.

Another factor that should also contribute to employee performance is Organizational Citizenship Behavior (OCB). According to (Organ \& Ryan, 1995), OCB is an individual contribution in the workplace that goes 
The Effect of Employee Engagement and Organizational Citizenship Behavior on the Performance of Employees of the Research \& Development and Education \& Training Agency of the Ministry of

Religion of the Republic of Indonesia

beyond the role required of a performance contract. OCB is one of the performance categories that are not easily explained by the work contract factor, which emphasizes the target by comparing it directly with high production rates (Smith et al. 1983). In a public sector organization, OCB is said to be important (Darto, 2014), who found that OCB has a vital role in improving individual performance in the public sector. OCB has a significant relationship with employee performance in the public sector. OCB helps change the formal organizational atmosphere to be a little relaxed and full of cooperation (Titisari, 2014). With this atmosphere, the tension between employees can be reduced. This supportive atmosphere will improve employee performance so that effectiveness and efficiency will be achieved. This is in line with Smith (1983), who states that OCB can smooth and smooth social life in an organization. With a good OCB, the social life of the IAARD Secretariat will run smoothly, and the performance will be more effective and efficient.

Based on preliminary research, organizational citizenship behavior of the Secretariat of the Research and Development and Training Agency employees is 58. The lowest OCB value is in the dimensions of conscientiousness and sportsmanship, with an average value of 52. This value is far from the target of 75 . Phenomenologically, it appears that senior employees are reluctant to help provide technical direction to their juniors because he was busy completing his task. Because they want to concentrate and don't want to be disturbed, the employee does not provide technical guidance, and it is impossible to give a warning because he is in a domain that is not included in the performance contract/SKP. The impact of the absence of technical guidance from senior employees causes the workflow to be disrupted because the work output produced by these juniors will become work input for other employees. These constraints cause the performance of other employees to be disturbed, and the overall performance of the organization will not be optimal.

There have been much literature describing the effect of OCB on employee performance. Some researchers argue that this influence is not direct but is mediated by several factors. Basu, Pradhan, and Tewari's research (Basu, Pradhan, \& Tewari, 2017) indicates that the effect of OCB on employee performance is indirect. Likewise, in the context of employee engagement, (Dajani 2015; Abdugapparovich, 2020) and (Ismail, Iqbal, \& Nasr, 2019) and (Albloush, Taha, Nassoura, \& Vij, 2020) suggest the need to examine the direct effect of employee engagement on employee performance in the context of national culture and the different nature of the organization. It is suspected that the differences in national culture and the nature of the organization may have a different influence on employee engagement on employee performance so that what applies in the Arabian Peninsula may be different from the enactment of employee engagement in other countries (Bin Shmailan, 2016). Likewise, it may apply to types of organizations where public sector organizations may have different outcomes than private organizations. The issue of inconsistency in the influence of OCB on employee performance will try to be traced in the context of religious organizations with the Indonesian locus. So the state of the art of this study is to investigate the direct influence of employee engagement and organizational citizenship behavior on employee performance in cases in public sector organizations in Indonesia.

Several experts have investigated the direct effect of employee engagement on employee performance. (Saks, 2006) found that there was a positive influence on employee engagement on employee performance. This research in 2019 was carried out again by reviewing the modeling carried out in 2006 by Saks with the results that it was proven that employee engagement had an effect on employee performance (Saks, 2019; Masri, 2020). (Dajani, 2015) in a study in Egypt found that employee engagement has a significant and positive effect on employee performance. (Bin Shmailan, 2016) found that employee engagement will increase employee productivity and retention. (Ismail et al., 2019) for the banking case in Lebanon also found the fact that employee engagement has a significant positive effect on employee performance. Based on the findings of previous research, the first hypothesis built in this study is:

H01: Employee engagement is proven to have a statistically significant effect on employee performance.

Ha1: employee engagement is not proven to have a statistically significant effect on employee performance.

The concept of OCB remains the focus of empirical research, as researchers recognize its practical implications for job performance and organizational success, such as competitive advantage and productivity (MacKenzie, Podsakoff, \& Fetter, 1993). Whiting et al. found that OCB has a significant effect on employee performance (Whiting, Podsakoff, \& Pierce, 2008). Testing was carried out using 2 study designs, namely voice and organizational loyalty, both of them have an effect on employee performance. This test is also corroborated by empirical research conducted by Chiang and Hsieh, who also found that organizational citizenship behavior has a positive effect on employee performance (Chiang \& Hsieh, 2012). Based on the description above, the second hypothesis is stated as follows: 
H02: Organizational citizenship behavior is statistically proven to have a positive effect on employee performance.

Ha2: Organizational citizenship behavior is not statistically proven to have a positive effect on employee performance.

Based on the information contained in the first two hypotheses above, which states that there is a positive influence on employee engagement and organizational citizenship behavior on employee performance, a third hypothesis is formed about the effect of both simultaneously on employee performance so that the third hypothesis is as follows:

H03: simultaneous employee engagement and organizational citizenship behavior is statistically proven to have a positive effect on employee performance.

Ha3: simultaneous employee engagement and organizational citizenship behavior is not statistically proven to have a positive effect on employee performance.

Considering the aforementioned problems, this study aims to determine whether: 1) employee engagement has a positive direct effect on the performance of the employees of the Secretariat of the Ministry of Religion's Research and Development Agency, 2) organizational citizenship behavior has a positive direct effect on the performance of the employees of the Secretariat of the Ministry of Religion Research and Training Agency, 3 ) simultaneous employee engagement and organizational citizenship behavior has a positive direct effect on the performance of the employees of the Secretariat of the Research and Development Agency and the Ministry of Religion.

\section{Methods}

\subsection{Sample and Data Collection}

This study's population was 58 employees who were echelon II in the Ministry of Religion, namely the Secretariat of the Research and Development and Training Agency. Based on 58 employees, the sample taken is a saturated sample referring to Sekaran (Sekaran \& Bougie, 2013). This type of saturated sample has the advantage in that the researcher has no bias in determining the sample (Salkind, 2003).

More than half of the respondents (62.1\%) were male, while the rest (37.9\%) were female. Based on their age, respondents who were up to 30 years old were $13.8 \%$. Respondents aged 31 to 40 years amounted to $37.9 \%$. Respondents aged 41 to 50 years amounted to $39.7 \%$. Respondents aged over 50 years amounted to $8.6 \%$.

Based on their latest education level, most respondents have a D1 to S1 education (55.2\%). The second place is junior high school to high school graduates at $29.3 \%$. Meanwhile, the S2 graduates were $15.5 \%$.

\subsection{Instrumentation}

Employee performance instrumentation is inspired by three dimensions from the four dimensions of Sunyoto (2016): quality, quantity, and timeliness using a 5 Likert scale consisting of statements with the lowest score strongly disagree and statements with the highest value agree for statements that are positive. Meanwhile, negative statements apply the opposite. "My work results are in accordance with the quality standard format set" and "My supervisor reviewed my work, and its content/substance was repeatedly corrected" is one of the sample items on this scale.

Employee engagement instrumentation is inspired by three dimensions of vigor, dedication, and absorption (Schaufeli, Salanova, González-romá, \& Bakker, 2002) using a 5 Likert scale consisting of statements with the lowest score strongly disagree and statements with the highest score strongly agree to positive statements. Meanwhile, negative statements apply the opposite. "I work with passion" and "I work until I lose track of time" are sample items on this scale.

The five dimensions of OCB inspire OCB instrumentation according to Organ in Allison et al. (Allison, Voss, \& Dryer, 2001), which was developed from (Aldag \& Reschke, 1997) by using a 5 Likert scale consisting of statements with the lowest score very not agree and the statement with the highest score strongly agrees for a positive statement. Meanwhile, negative statements apply the opposite. "I work to replace colleagues who have many workloads" and "I do not ask for additional breaks even though yesterday was very hard work" is one sample item on this scale. 
The Effect of Employee Engagement and Organizational Citizenship Behavior on the Performance of Employees of the Research \& Development and Education \& Training Agency of the Ministry of

Religion of the Republic of Indonesia

\section{Results and Discussions}

\section{Hypothesis Test}

By using multiple regressions testing, the results obtained by the value of the impact of individual employee engagement and organizational citizenship behavior on performance are as follows:

Table 1. Individual Regression Results

\begin{tabular}{llll}
\hline & Std Coefficient $\beta$ & $\mathrm{T}$ & $\mathrm{Sig}$. \\
\hline Employee Engagement & 0.673 & 4.552 & 0.000 \\
Organizational Citizenship Behavior & -0.136 & -0.920 & 0.362 \\
\hline
\end{tabular}

Predictor is employee performance

By using multiple regressions testing, the results of the simultaneous impact of individual employee engagement and organizational citizenship behavior on performance were obtained as follows:

Table 2. Simultaneous Regression Results

\begin{tabular}{lllll}
\hline & df & R Square & F & Sig. \\
\hline Regression & 2 & 0.347 & 14.638 & 0.000 \\
Residual & 55 & & & \\
Total & 57 & & & \\
\hline
\end{tabular}

Predictor: Employee engagement, Organizational Citizenship Behavior,

Dependent variable: Employee performance

\section{The Effect of Employee Engagement on Employee Performance}

The direct effect of employee engagement on performance is shown in the employee engagement row in the Standardized Coefficient Beta column. In this column, it is shown that the value of the direct effect of employee engagement on employee performance is (positive) 0.673. So that the magnitude of this number proves that employee engagement has a positive direct effect on employee performance.

To determine the significance of the effect of employee engagement on performance, additional information is needed from table 1 in the employee engagement row column $t$ and sig. employee engagement column $t$ shows the $t$-count 4,552 . This $t$-count can determine the significance level of the influence of employee engagement by comparing it with the $t$ table.

To determine the number on the table we need some information, namelya (level of significance), the number of samples, and the number of exogenous variables. The value of $t$ table is simply obtained by the notation $(\alpha ; \mathrm{dk}=\mathrm{n}-\mathrm{k}-1)$ (Riduwan \& Kuncoro, 2014). In our assumption test, the $\alpha$ value is 0.05 . The value of $\mathrm{n}$ is the number of samples as much as 58 . The value of $\mathrm{k}$ is the number of exogenous variables of 2 . Then the $\mathrm{t}-$ table that is looking for is $(0.05 ; 58-2-1=55)$. On the $\mathrm{t}$-table with this number the figure is 2.004044783 . Then the $\mathrm{t}$-count is 4,552> t-table 2,004, according to Sujarweni (2014), if the t-count> $\mathrm{t}$-table means that the independent variable $(\mathrm{X})$ partially has a significant effect on the dependent variable $(\mathrm{Y})$. Thus the independent variable (employee engagement) partially has a significant effect on the dependent variable (employee performance).

The significance of the effect of employee engagement on performance is also shown in other sections in table 1. On the employee engagement row, the sig column shows the value of 0.000 . This value states the significance of employee engagement on employee performance. According to Imam Ghozali (2011), the criteria for the effect of a variable partially is if the value is sig. $<0.05$, it means that the independent variable $(\mathrm{X})$ partially has a significant effect on the dependent variable (Y). Likewise this applies to the opposite value.

Based on the three indicators above, it can be stated that the first hypothesis that "employee engagement directly, positively and significantly influences employee performance" is accepted.

\section{The Influence of Organizational Citizenship Behavior on Employee Performance}

The direct effect of organizational citizenship behavior on performance is shown in the row of organizational citizenship behavior in the Standardized Coefficient Beta column (Riduwan \& Kuncoro, 2014). In this column it 
is shown that the value of the direct effect of organizational citizenship behavior on employee performance is 0.136 which is negative. So that the load of these numbers states that organizational citizenship behavior has a negative direct effect on employee performance.

To determine the significance of the effect of organizational citizenship behavior on performance requires additional information from table 1 on the row organizational citizenship behavior column $\mathrm{t}$ and sig. organizational citizenship behavior column $\mathrm{t}$ shows the $\mathrm{t}$-count -0.920 . This $\mathrm{t}$-count can determine the level of significance of the effect of organizational citizenship behavior by comparing it with the t-table.

To determine the number on the table we need some information, namely $\alpha$ (level of significance), the number of samples, and the number of exogenous variables. The value of t-table is simply obtained by the notation ( $\alpha ; \mathrm{dk}=\mathrm{n}-\mathrm{k}-1)$ (Riduwan \& Kuncoro, 2014). In our assumption test, the $\alpha$ value is 0.05 . The value of $\mathrm{n}$ is the number of samples as much as 58 . The value of $\mathrm{k}$ is the number of exogenous variables of 2 . Then the $\mathrm{t}-$ table that is looking for is $(0.05 ; 58-2-1=55)$. On the $\mathrm{t}$-table with this number the figure is 2.004044783 . Then the t-count $-0.920<\mathrm{t}$-table 2.004 , according to Sujarweni (2014), if the t-count $<\mathrm{t}$-table, it means that the independent variable $(\mathrm{X})$ partially has no significant effect on the dependent variable $(\mathrm{Y})$. Thus the independent variable (organizational citizenship behavior) partially has no significant effect on the dependent variable (employee performance).

The significance of the effect of organizational citizenship behavior on performance is also seen in other parts of table 1. In the row of Organizational Citizenship Behavior, the sig column shows a value of 0.362 . This value states the significance of organizational citizenship behavior on employee performance. According to Imam Ghozali (2011), the criteria for the effect of a variable partially is if the value is sig. $>0.05$, it means that the independent variable $(\mathrm{X})$ partially has no significant effect on the dependent variable (Y). Likewise this applies to the opposite value. The sig value of $0.362>0.05$ means that the independent variable (organizational citizenship behavior) partially has no significant effect on the dependent variable (employee performance).

Based on the three indicators above, it can be stated that the variable organizational citizenship behavior has a negative and insignificant direct effect on employee performance, this finding thus rejects the second hypothesis that "organizational citizenship behavior directly, positively and significantly affects employee performance".

\section{The Effect of Employee Engagement and Organizational Citizenship Behavior Simultaneously on Employee Performance}

The direct effect of employee engagement, organizational citizenship behavior together/simultaneously on employee performance is shown in the regression row in the R Square column. In the R Square column, it is shown that the value of employee engagement, organizational citizenship behavior together/simultaneously on employee performance is (positive) 0.347. This figure means that simultaneously employee engagement and organizational citizenship behavior has a direct effect on employee performance by $34.7 \%$ (Riduwan \& Kuncoro, 2014). The remaining $65.3 \%$ of employee performance scores are influenced by other factors that cannot be explained in the study. The magnitude of this number proves that employee engagement and organizational citizenship behavior simultaneously has a positive direct effect on employee performance.

To determine the significance of the effect of employee engagement on performance, additional information is needed from table 2 in the regression row column F and sig. In column F shows the number F-count 14.638. This F-count can determine the significance level of the influence of employee engagement and organizational citizenship behavior simultaneously on employee performance by comparing it with F-table.

To determine the number in F-table we need some information, namely $\alpha$ (level of significance), number of samples, and number of exogenous variables. The value of Ftable is simply obtained by the notation $\{(\alpha)$; $(\mathrm{dk}=$ $\mathrm{k}) ;(\mathrm{dk}=\mathrm{n}-\mathrm{k}-1)$ ) (Riduwan \& Kuncoro, 2014). In our assumption test, the $\alpha$ value is 0.05 . The value of $\mathrm{n}$ is the number of samples as much as 58 . The value of $k$ is the number of exogenous variables as much as 2 . Then the $t-$ table that is looking for is $(0.05 ; 2 ; 58-2-1=55)$. In F-table with this figure, the figure is 3.164993396 . Then the F-count is 14.638> t-table 3.165, according to Sujarweni (2014), if the value of F-count> F-table means that the independent variable (employee engagement and organizational citizenship behavior) simultaneously has a significant effect on the dependent variable (employee performance).

The significance of the effect of employee engagement and organizational citizenship behavior simultaneously on performance is also seen in other parts of table 4. In the regression row, the sig column is 
written with a value of 0.000 . This value states the significance of employee engagement and organizational citizenship behavior simultaneously on employee performance. The criterion about the significant effect of a variable is if the value is sig. $<0.05$ significance level means that the independent variable $(\mathrm{X})$ partially has a significant effect on the dependent variable (Y) (Imam Ghozali, 2011). Based on these criteria, the sig value is $0,000>$ a significance level of 0.05 , so it can be said that employee engagement and organizational citizenship behavior simultaneously affects employee performance.

Based on three indicators in the form of $\mathrm{R}$ square value, F-count value and sig value, it can be stated that the third hypothesis that "employee engagement and organizational citizenship behavior simultaneously directly, positively and significantly influences employee performance" is accepted.

\section{Conclusion}

The discussion of the research results referred to in this study is to seek answers between theoretical studies and empirical studies of this research. Based on the results of hypothesis testing in this study on the three variables, the results are that two hypotheses are accepted and one hypothesis is rejected. Two hypotheses accepted are "employee engagement has a positive direct effect on the performance of the employees of the Secretariat of the Ministry of Religion Research and Development Agency" and "employee engagement and organizational citizenship behavior simultaneously has a direct, positive effect on the performance of the employees of the Secretariat of the Ministry of Religion Research and Training Agency". The hypothesis that was rejected was that "organizational citizenship behavior has a direct, positive effect on the performance of the employees of the Secretariat of the Ministry of Religion's Research and Development Agency and Training Agency". This can be described in the discussion of the research results as follows:

Based on multiple regression calculations with the help of the SPSS 18 application, the regression coefficient of employee engagement on the performance of the employees of the Secretariat of the Research and Development Agency of the Ministry of Religion of the Republic of Indonesia is positive at 0.673. Sig value. $0.000<\alpha$ of 0.05 so it can be stated that this value is statistically significant. This shows that employee engagement has a positive and significant direct effect on the performance of the employees of the Secretariat of the Research and Development Agency and the Ministry of Religion of the Republic of Indonesia.

This finding supports several relevant studies that previous researchers, namely the research of Saks, Dajani, Bin Shmailan, and research of Ismail et al, which stated that employee engagement has a positive direct effect on employees.

Based on the calculation of multiple regressions with the help of the SPSS 18 application, the regression coefficient of organizational citizenship behavior on the performance of the employees of the Secretariat of the Research and Development Agency and the Ministry of Religion of the Republic of Indonesia is valued at 0.136 . Sig value. $0.362>\alpha$ of 0.05 , so it can be stated that this value is not statistically significant. This shows that organizational citizenship behavior has a direct negative effect but the effect is not significant on the performance of the employees of the Secretariat of the Research and Development Agency and the Ministry of Religion of the Republic of Indonesia.

This finding is different from several relevant studies where previous researchers, namely the research of Whiting, Chiang \& Hsieh, which stated organizational citizenship behavior has a direct and positive effect on employee performance. The difference in the findings of this study compared to the two previous studies lies in the research locus. In Chiang \& Hsieh's research, the research locus was in the private sector, namely hotel employees in Taiwan. Whiting, Podsakoff and Pierce conducted research at a public university in the United States. This research is applied in Indonesia, whose work ethic is different from the two more developed countries. Based on the organization, this research was conducted in a public organization whose work ethic image is lower than that of private organizations in general. The Ministry of Religion as well as the Bureaucratic Reform Report of the Ministry of PAN and RB of 4,484 work units as of 12 December 2019 has only succeeded in eliminating 10 of its work units which are good for national services (in terms of service quality and corruption perception index) and this research locus (Secretariat of the Research and Development and Education and Training Agency) is not included in it.

Based on multiple regression calculations with the help of the SPSS 18 application, the regression coefficients of employee engagement and organizational citizenship behavior were obtained simultaneously on the performance of the employees of the Secretariat of the Research and Development Agency of the Ministry of 
Religion of the Republic of Indonesia with an $\mathrm{R}$ squared of 0.347 . This value means that the two variables, namely employee engagement and organizational citizenship behavior, simultaneously have a direct effect on the performance of the employees of the Secretariat of the Research and Development Agency and the Ministry of Religion of the Republic of Indonesia by 34.7\%. Thus $34.7 \%$ of the variation in the performance of the employees of the Secretariat of the Research and Development Agency of the Ministry of Religion can be explained by the variables of employee engagement and organizational citizenship behavior while the remaining $65.3 \%$ is influenced by other factors that are not included in the research model.

Simultaneously, employee engagement and organizational citizenship behavior has a sig value. $0.000<\alpha$ of 0.05 so it can be stated that this value is statistically significant. In other words, it can be concluded that the regression model used to determine the effect of employee engagement and organizational citizenship behavior together has an effect on the performance of the employees of the Secretariat of the Research and Development Agency and the Ministry of Religious Affairs or can also be worth it.

\section{References}

1. Albloush, S. Taha, A. Nassoura, and A. Vij, "Impact of Organizational Citizenship Behavior on Job Performance in Jordan: The Mediating Role of Perceived Training Opportunities", International Journal of Psychosocial Rehabilitation, vol. 24, no. 05, pp. 5584-5600, 2020. https://doi.org/10.37200/IJPR/V24I5/PR2020264

2. N.U. Abdugapparovich, "Measures to Ensure Employment in Uzbekistan Through the Support of Small Business and Entrepreneurship", Indonesian Journal of Social and Environmental Issues (IJSEI), vol. 1, no. 2, pp. 69-72, 2020. https://doi.org/10.47540/ijsei.v1i2.16

3. R. Aldag, and W. Reschke, "Employee Value Added: Measuring Discretionary Effort and Its Value ti the Organization”, Center for Organization Effectiveness, vol. 608, pp. 833-3332, 1997.

4. M.B. Alexandri, N. Kostini, and E. Maulina, Employee Empowerment, Psycological Contract, Employee Engagement di Universitas di Indonesia. Responsive. 2019. https://doi.org/10.24198/responsive.v1i2.20678

5. B.J. Allison, R.S. Voss, and S. Dryer, "Student Classroom and Career Success: The Role of Organizational Citizenship Behavior", Journal of Education for Business, vol. 76, no. 5, pp. 282-288, 2001. https://doi.org/10.1080/08832320109599650

6. E. Basu, R.K. Pradhan, and H.R. Tewari, "Impact of organizational citizenship behavior on job performance in Indian healthcare industries: The mediating role of social capital", International Journal of Productivity and Performance Management, vol. 66, no. 6, pp. 780-796, 2017. https://doi.org/10.1108/IJPPM-02-2016-0048

7. A.S. Bin Shmailan, "The relationship between job satisfaction, job performance and employee engagement: An explorative study", Issues in Business Management and Economics, vol. 4, pp. 1-8, 2016. https://doi.org/http://dx.doi.org/10.15739/IBME.16.001

8. C.F. Chiang, and T.S. Hsieh, "The impacts of perceived organizational support and psychological empowerment on job performance: The mediating effects of organizational citizenship behavior", International Journal of Hospitality Management, vol. 31, no. 1, pp. 180-190, 2012. https://doi.org/10.1016/j.ijhm.2011.04.011

9. M.A.Z. Dajani, "The Impact of Employee Engagement on Job Performance and Organisational Commitment in the Egyptian Banking Sector", Journal of Business and Management Sciences, vol. 3, no. 5, pp. 138-147, 2015. https://doi.org/10.12691/jbms-3-5-1

10. M. Darto, "The Role of Organizational Citizenship Behavior (Ocb) in Increasing Individual Performance in the Public Sector: A Theoretical and Empirical Analysis", Borneo Administrator Journal, vol. 10, no. 1, pp. 10-34, 2014.

a. Ghozali, Multivariate application with the IBM SPSS 19 program. Semarang: Diponegoro University Publishing Agency, 2011.

11. H.N. Ismail, A. Iqbal, and L. Nasr, Employee engagement and job performance in Lebanon: the mediating role of creativity. International Journal of Productivity and Performance Management, 2019. https://doi.org/10.1108/IJPPM-02-2018-0052

12. S.B. MacKenzie, P.M. Podsakoff, and R. Fetter, "The Impact of Organizational Citizenship Behavior on Evaluations of Salesperson Performance", Journal of Marketing, vol. 57, no. 1, pp. 70-80, 1993. https://doi.org/10.2307/1252058

13. M. Masri, "Implementation of Leadership Strategies and Work Commitments in Maintaining Employee Performance in CV. Silvana Print \& Advertising Kendari City Southeast Sulawesi", Indonesian Journal of Social and Environmental Issues (IJSEI), vol. 1, no. 2, pp. 91-96, 2020. https://doi.org/10.47540/ijsei.v1i2.59 
The Effect of Employee Engagement and Organizational Citizenship Behavior on the Performance of Employees of the Research \& Development and Education \& Training Agency of the Ministry of

Religion of the Republic of Indonesia

14. D.W. Organ, and K. Ryan, A Meta-Analytic Review of Attitudinal and Dispositional Predictors of Organizational Citizenship Behavior. Personnel Psychology, vol. 48, no. 4, pp. 775-802, 1995. https://doi.org/10.1111/j.1744-6570.1995.tb01781.x

15. T. Purnamie, "The role of organizational citizenship behavior (OCB) in improving employee performance”, Jakarta: Mitra Wacana Media, 2014.

16. R. Riduwan, and E.A. Kuncoro, How to Use and Interpret Path Analysis (Keenam; Akdon, ed.). Bandung: Alfabeta, 2014.

17. A.M. Saks, "Antecedents and consequences of employee engagement", Journal of Managerial Psychology, vol. 21, no. 7, pp. 600-619, 2006. https://doi.org/10.1108/02683940610690169

18. A.M. Saks, "Antecedents and consequences of employee engagement revisited", Journal of Organizational Effectiveness: People and Performance, vol. 6, no. 1, pp. 19-38, 2019. https://doi.org/10.1108/JOEPP-06-2018-0034

19. N.J. Salkind, "Exploring Research (5th ed.)." Pennsylvania: Prentice Hall, 2003. https://books.google.co.id/books?id=HGgbAQAAMAAJ

20. W. Schaufeli, M. Salanova, V. González-romá, and A. Bakker, "The Measurement of Engagement and Burnout: A Two Sample Confirmatory Factor Analytic Approach”, Journal of Happiness Studies, vol. 3, no. 1, pp. 71-92, 2002. https://doi.org/10.1023/A:1015630930326

21. U. Sekaran, and R. Bougie, “Business Research Methods: A skill-building approach”, In Wiley, 2013.

22. C.A. Smith, D.W. Organ, and J.P. Near, "Organizational citizenship behavior: Its nature and antecedents", Journal of Applied Psychology, vol. 68, no. 4, pp. 653-663, 1983. https://doi.org/10.1037/0021-9010.68.4.653

23. Sugiyono. (2017). Combined research methods (Mixed Methods). In Alfabeta (Cet 9). Bandung: Alfabeta.

24. V.W. Sujarweni, “SPSS for Research”, Yogyakarta: Pustaka Baru Press, 2014.

25. D. Sunyoto, “Management and Human Resources Development”, Yogyakarta: Center for Academic Publishing Service, 2015.

26. S.W. Whiting, P.M. Podsakoff, and J.R. Pierce, "Effects of Task Performance, Helping, Voice, and Organizational Loyalty on Performance Appraisal Ratings", Journal of Applied Psychology, vol. 93, no. 1, 125-139, 2008. https://doi.org/10.1037/0021-9010.93.1.125 